\title{
Strategi penjualan polis asuransi kebakaran Studi kasus: PT. Asuransi Jasa Indonesia Cabang Pekanbaru
}

\author{
Qomariah Lahamid $^{1^{*}}$, Hafizah Indriyanti ${ }^{2}$ \\ ${ }^{1,2}$ UIN Sultan Syarif Kasim Riau. \\ *Correspondentemail : qomariah.l@uin-suska.ac.id
}

\begin{abstract}
This study aims to determine the sales strategy carried out by PT. Pekanbaru Indonesia Services Insurance Branch. This research is a qualitative descriptive study. The data used in this language are secondary and primary data. The informants in this study were the leadership and marketing division of PT. Insurance Services Indonesia Pekanbaru Branch. The results showed that there are several sales strategies implemented by the company, namely E-Commerce, direct selling, selling and marketing by telephone, company referrals, and mail orders. The suggestion from this research is that it is necessary to improve the promotion strategy through brochures, advertisements, TV shopping and others, so that the public can see Jasindo's insurance products, including fire insurance. Then, further improve service to customers.
\end{abstract}

Keywords: Sales strategy; fire insurance policy

\section{PENDAHULUAN}

Kepastian yang dihadapi manusia salah satunya adalah resiko yang tidak dapat dilepaskan dari kehidupan semua orang. Resiko yang dihadapi akan menimbulkan kerugian dan tidak seorangpun bisa menghindarinya. Banyak ragam resiko yang ada yang dapat mempengaruhi harta kepemilikan seseorang ataupun perusahaan bahkan Negara. Tetapi, manusia tidak dibenarkan menyerah begitu saja tanpa usaha yang maksimal dalam penghindaran resiko, melainkan justru merupakan tantangan untuk melakukan suatu tindakan yang dapat memberikan perlindungan kepada masyarakat dari setiap risiko yang terjadi. Sebab pada dasarnya setiap orang ingin mendapat suatu perlindungan.

Salah satu cara seseorang agar mendapat perlindungan saat menghadapi resiko pada zaman modern ini yaitu dengan asuransi. Dengan asuransi orang dapat mengalihkan atau melimpahkan risiko-risiko tersebut kepada pihak lain yang memang mengkhususkan usahanya di bidang tersebut. Industri Asuransi di Indonesia sesungguhnya telah puluhan tahun dikenal masyarakat. namun pertumbuhannya relatif lambat dibandingkan dengan potensi usaha yang sudah ada. Setiap perusahaan asuransi cenderung memilih underinvestment ketika efek spillover relatif besar dan ketika efek perubahan permintaan tidak negatif. Dalam hal ini, mencapai pasar asuransi yang koopetitif melalui asosiasi asuransi menciptakan nilai lebih dalam tahap investasi. (Okura, 2007)

Dalam melaksanakan bisnis asuransi, peraturan asuransi dan dukungan dari pemerintah sangatlah diperlukan. Perusahaan-perusahaan asuransi akan berkembang, kemudian makin banyak produk asuransi yang bermunculan dengan berbagai kelebihan. Layanan purna jual, jumlah premi yang cukup rendah dan dapat dijangkau oleh masyarakat yang berpenghasilan tidak tinggi, dan layanan lain- lainnya. Salah satu proteksi atau perlindungan asuransi yang dapat dinikmati masyarakat terhadap resiko yang dihadapi baik individu, keluarga maupun bisnis adalah perlindungan atas kebakaran. Asuransi kebakaran bertujuan untuk mengganti kerugian-kerugian yang disebabkan oleh kebakaran atau segala sesuatu yang tidak dapat diprediksi sesuai isi polis dan lampiran-lampirannya.(Pamungkas* et al., 2017).

Kebakaran bangunan, gedung, rumah masih sering terjadi dimana-mana. Informasi ini sering kita dapatkan dari berita-berita media online atau TV. Di Indonesia saat ini masih sulit untuk menyadarkan bahwa asuransi kebakaran itu juga penting, hal itu dikarenakan kurangnya pemahaman mereka tentang apa itu asuransi kebakaran. Berbeda dengan di luar negeri yang mayoritas mereka menggunakan asuransi selama hidupnya baik sumber daya manusianya termasuk kendaraan dan gedung yang mereka punya. Pihak asuransi juga dituntut piawai dalam menjual produk asuransi kebajaran ini. Penelitian Pratama (2017) menunjukkan bahwa strategi promosi dan kualitas layanan baik secara parsial 
maupun simultan berpengaruh terhadap peningkatan penjualan di Ovan Putri Bridal and Makeup Surabaya.

Tabel berikut menjelaskan target dan realisasi penjualan Polis asuransi pada PT. Asuransi Jasindo Cabang Pekanbaru.

Tabel 1. Target dan Realisasi Penjualan Polis Asuransi Pada PT. Asuransi Jasindo Cabang Pekanbaru

\begin{tabular}{ccccc}
\hline No & Tahun & Target Penjualan & Realisasi Penjualan & Persentase Realisasi \\
\hline 1 & 2015 & 4.070 .000 .000 & 2.828 .725 .000 & $70 \%$ \\
2 & 2016 & 3.500 .000 .000 & 2.907 .968 .000 & $83 \%$ \\
3 & 2017 & 3.190 .000 .000 & 7.380 .484 .000 & $231 \%$ \\
4 & 2018 & 8.150 .000 .000 & 15.329 .841 .000 & $188 \%$ \\
\hline 5 & 2019 & 18.700 .000 .000 & 6.572 .725 .000 & $35 \%$ \\
\hline
\end{tabular}

Sumber: PT. Asuransi Jasindo 2019

Berdasarkan tabel 1 tampak bahwa tidak tercapainya target yang sudah disusun oleh perusahaan kecuali pada tahun 2018. Realisasi tahun 2015 yaitu sebesar $70 \%$ dari target yang direncanakan. Tahun 2017 dan 2018 terjadi realisasi yang melebihi target yaitu masing-masing 231\% dan 188\%. Malangnya, pada tahun 2019, realisasi hanya sebesar 35\%. Tampak beberapa masalah tidak tercapainya realisasi penjualan yang dihadapi oleh PT. Asuransi Jasindo beberapa tahun sebelumnya.

Dalam meningkatkan volume penjualan maka harus dengan pemasaran yang tepat dan baik, karena dengan baiknya cara memasarkan sebuah produk atau jasa maka hal itu akan membuat penjualan meningkat. Perlu strategi yaitu, rencana yang cermat mengenai kegiatan untuk mencapai sasaran khusus atau rencana untuk memperbesar pengaruh terhadap pasar baik dalam jangka pendek maupun jangka panjang, yang didasarkan pada riset pasar, penilaian dan perencana produk. (Darmanto, 2015). Produk, harga dan promosi positif dan sigifikan mempengaruhi kinerja penjualan. (Nasution et al., 2107). Hasil berdasarkan analisis regresi linier berganda menunjukkan bahwa variabel periklanan berpengaruh positif dan signifikan terhadap penjualan volume suku cadang.(Siregar, 2017). Berdasarkan latar belakang tersebut, penelitian ini bertujuan mengetahui strategi penjualan polis asuransi kebakaran yang ada pada PT. asuransi jasa Indonesia cabang Pekanbaru, Riau.

\section{METODE PENELITIAN}

Penelitian ini dilakukan di kantor Asuransi Jasa Indonesia Cabang Pekanbaru yang beralamatkan di J1. Jendral Sudirman Pekanbaru, Riau. Penelitian ini menggunakan analisis deskriptif kualitatif yaitu data yang dikumpul di analisis dengan memberikan gambaran secara rinci berdasarkan pernyataan yang ada di lapangan.

Data yang digunakan dalam penulisan ini adalah data sekunder dan primer. Data primer adalah data yang diperoleh secara langsung dari objek atau lokasi penelitian, seperti struktur organisasi, sejarah singkat perusahaan, dan lainnya. wawancara dilakukan secara langsung menemui pimpinan perusahaan dan beberapa staf dan sales marketing perusahaan. Data sekunder adalah data yang diperoleh melalui sumber - sumber yang berhubungan dengan penelitian, pendapat para ahli, dan buku penunjang lainnya.

Untuk memperoleh data yang akurat agar dapat menjawab beberapa permasalahan dalam penelitian, digunakan beberapa teknik pengumpulan data yaitu, pertama, wawancara terstruktur yaitu melakukan tanya jawab langsung dengan responden untuk mendapatkan informasi tentang pelaksanaan strategi penjualan polis asuransi kebakaran yang ada pada PT. asuransi jasa Indonesia cabang Pekanbaru, Riau. Kedua, observasi yaitu mengambil langsung objek penelitian dalam waktu, keadaan dan tempat penelitian di PT. asuransi jasa Indonesia cabang Pekenbaru, Riau. Ketiga, analisis data dengan mengumpulkan data dan informasi dalam penyusunan penelitian ini.

\section{HASIL DAN PEMBAHASAN}

Strategi penjualan merupakan proses yang dapat memberikan efek peningkatan pada nilai penjualan. Biasanya strategi penjualan yang menarik menjadikan konsumen lebih tertarik dibandingkan dengan cara menoton yang sudah biasa dilakukan banyak orang. Adapun strategi penjualan dibutuhkan agar konsumen merasa nyaman dan tertarik untuk membeli dengan cara yang dilakukan. Terdapat beberapa strategi yang dipergunakan oleh kantor asuransi jasa Indonesia cabang Pekanbaru 
diantaranya: Menurut Bapak irfan Fadhillah selaku Kepala Marketing Kantor Asuransi Jasa Indonesia Cabang Pekanbaru strategi yang digunakan dalam memasarkan dan menjualkan polis asuransi kebakaran. Strategi pertama yaitu strategi promosi. Promosi adalah salah satu cara yang dilakukan oleh tiap perusahaan untuk memasarkan atau menginformasikan kepada banyak orang agar mereka tertarik dengan apa yang kita miliki, namun tiap perusahaan memiliki cara yang berbeda- beda dalam mempromosikan pereusahaannya, kegiatan yang dilakukan oleh jasindo adalah E-Commerce/website. Seiring dengan perkembangan zaman maka jasindo juga memiliki website yang diberi nama jasindo.co.id dengan adanya website maka dengan ini masyarakat dapat mengakses dan mencari tahu tentang jasindo lebih banyak. Website juga berfungsi sebagai sarana informasi bagi masyarakat.

Sosialisasi/seminar merupakan cara promosi yang kedua dilakukan oleh asuransi Jasindo. Sosilaisasi dilakukan oleh Jasindo secara berkala untuk memperkenalkan perusahaan kepada banyak orang secara langsung dan dihadapan banyak orang, sosialisasi dilakukan sebagai bentuk edukasi perusahaan kepada masyarakat agar masyarakat mengetahui dan memahami tentang Jasindo dan produk yang dimiliki, biasanya sosialisasi dilakukan oleh jasindo kepada daerah-daerah tertentu, pada dasarnya sosialisasi ini dilakukan untuk memperkenalkan asuransi pertanian, peternakan atau nelayan. Namun sosialisasi juga dilakukan kepada perusahaan, kampus dan sekolah yang dilakukan oleh tim marketing jasindo cabang Pekanbaru. Sosialisasi tidak hanya dilakukan oleh tim marketing jasindo saja namun juga oleh agen asuransi yang sudah terdaftar sebagai agen Jasindo. Dalam sosialisasi ini pihak asuransi akan tentang prosuk asuransi kebakaran dan produk-produk asuransi lainnya.

Sosialisasi dilakukan secara berkala tiap tim marketing dan agen memiliki fungsi dan tanggung jawab yang berbeda, hal yang pertama dilakukan sebelum sosialisasi adalah mapping hal itu dilakukan oleh tim marketing agar mempermudah dalam kunjungan jadwal perusahaan. Tim marketing asuransi memiliki tugas dan tanggung jawab yang berbeda-beda.

Selain promosi, Jasindo melakukan Direct Selling. Dengan memiliki produk ssuransi yang cukup banyak, maka Jasindo perlu melakukan penjualan secara langsung (direct selling). Biasanya hal ini dilakukan oleh agen-agen asuransi jasa Indonesia yang melakukan penjualan secara langsung kepada calon nasabah. Agen asuransi mencari calon nasabah baik kesekolah, kampus dan lainnya sehingga proses pemasaran dan penjualan menjadi lebih baik karena agen asuransi yang bekerja secara maksimal dan dengan demikian agen asuransi juga mendapatkan fee dari hasil yang telah di dapat. Asuransi kebakaran lebih banyak dipromosikan pada perusahaan-perusahaan yang memiliki resiko besar akan terjadi kebakaran, sekolah-sekolah swasta, kampus-kampus dan individu-individu yang memang ingin mendapat perlindungan harta dari resiko kebakaran. Penelitian Maroffi menjelaskan bahwa strategi penjualan memiliki pengaruh yang signifikan terhadap kinerja. Hubungan antara perusahaan asuransi dan kinerja strategi penjualan baik secara langsung dan tidak langsung secara signifikan berpengaruh terhadap kinerja penjualan.(Maroofi et al., 2017).

- Tahun - Jumlah Nasabah

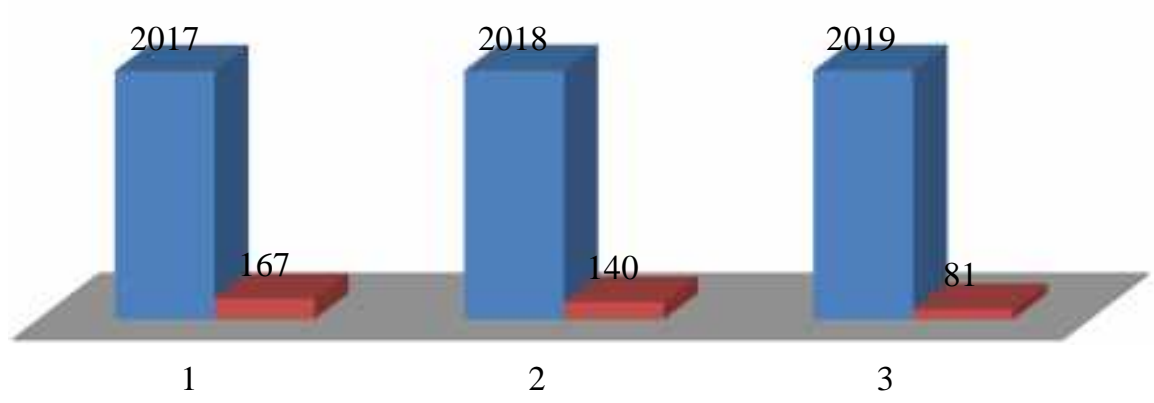

Gambar 1. Data jumlah nasabah polis asuransi kebakaran tiga tahun terakhir. Sumber: PT. Asuransi Jasa Indonesia Cabang Pekanbaru 2019

Dari gambar 1 menunjukkan bahwa jumlah nasabah asuransi kebakaran Jasindo cukup banyak dan berfluktuasi dalam tiga tahun tersebut. Namun dari angka nasabah, Jasindo optimis ke depannya mampu meningkatkan jumlah nasabah. Stategi selanjutnya yaitu Telemarketing/teleshopping. Strategi ini dilakukan dengan cara menelpon nasabah secara langsung. Biasanya hal ini dilakukan kepada nasabah baru untuk follow up atau menanyakan lebih lanjut kepada calon nasabah, apakah mereka ingin menjadi mitra atau 
nasabah tetap jasindo, hal ini dilakukan setelah calon nasabah baru sudah dapat perhitungan dari harga premi yang telah diberikan.

Menelfon nasabah tidak hanya dilakukan untuk calon nasabah baru saja, melainkan juga untuk nasabah yang sudah lama, hal ini dilakukan semisal nasabah belum membayarkan premi polis asuransi tepat pada waktunya, maka sudah menjadi tugas dari marketing asuransi untuk mengingatkan nasabah membayar premi yang sudah ditetapkan, atau menelfon nasabah apabila nasabah sudah tidak mau lagi bermitra dengan jasindo. Dengan kata lain menelfon nasabah dilakukan untuk membujuk dan merayu nasabah agar mau menjadi nasabah tetap Jasindo, namun hal ini dilakukan apabila jarak dan waktu yang tidak memungkinkan bagi marketing untuk menemui nasabah secara langsung. Sejalan dengan Arifin dalam buku Sopiah dan Sangadji (2016:51) ada lima strategi dalam penjualan yaitu, Penjualan konvensional, Konsinyasi, Direct selling, Telemarketing, Member Get Member (MGM). Selain lima strategi penjualan diatas, terdapat sepuluh strategi penjualan lainnya yang yaitu sebagai berikut: Cross Selling, Take One Boxes, TV Shopping, Mail Order, Telephone Shopping, Company Referral, Multi Level Marketing, E-Commerce, Program Afiliasi, Viral Marketing

Strategi selanjutnya yaitu pada Product. Fire Insurance (asuransi kebakaran) adalah salah satu produk asuransi yang dimiliki oleh jasindo, asuransi kebakaran adalah produk asuransi yang menjamin resiko kerugian atau kerusakan yang terjadi pada harta benda terhadap resiko yang dijamin dalam polis standar asuransi kebakaran Indonesia (PSAKI). Asuransi ini juga dikenal dengan asuransi semua resiko harta benda. Beberapa hal yang dijamin yaitu, Property. Luas jaminan seperti standard (PSAKI : kebakaran, petir, peledakan, tertimpa kapal terbang), perluasan (gempa bumi, huru hara, banjir, d1l), all risks, Business Interruption, Company Referral. Company Referral berupa kerjasama dengan perusahaan lain, seperti bank, adapun bank yang saat ini bekerjasama dengan jasindo adalah bank Riau Kepri, bank mandiri, bank BRI dan Bank BNI. Nasabah bank yang melakukan peminjaman kepada bank akan menitipkan harta yang dia miliki baik itu berupa rumah, mobil, dan lain sebagainya. Kemudian bank akan mencari perusahaan asuransi untuk menjadi jaminan untuk harta benda yang ditinggalkan atau yang menjadi agunan bagi nasabah. Terakhir, Mail order yaitu menggunakan jasa pos yang disebut dengan ekspedisi seperti $J \& T$, Tiki dll atau pengiriman barang, biasanya hal ini dilakukan apabila polis sudah di cetak dan tinggal melakukan pengiriman ke rumah nasabah. Hal ini dilakukan apabila kediaman nasabah cukup jauh sehingga tidak dapat dijangkau oleh tim marketing.

\section{KESIMPULAN}

Berdasarkan penjabaran tersebut, dapat disimpulkan bahwa strategi penjualan polis asuransi kebakaran dilakukan dengan E-Commerce, Direct selling, Penjualan dan memasarkan melalui telephone, Company referral, Mail order. Adapun saran dari penelitian ini dalam penjualan hendaknya asuransi jasa Indonesia juga meningkatkan strategi promosinya, baik berupa brosur, afiliasi (iklan), Tv shopping dan lainnya, sehingga dengan demikian masyarakat dapat mengetahui tentang jasindo dan produk yang dimiliki dan penggunaan media sosial. Kemudian, Meningkatkan pelayanan, meskipun saat ini nasabah sudah merasa nyaman dan puas dengan pelayanan yang diberi namun tidak ada salahnya untuk meningkatkan pelayanan yang jauh lebih baik.

\section{UCAPAN TERIMAKASIH}

Membuat artikel ilmiah memerlukan proses hingga layak untuk diterbitkan. Penulis dalam membuat artikel ini mengikuti arahan dari reviewer, editor dan ketentuan-ketentuan jurnal synergy. Untuk itu, penulis mengucapkan terimakasih atas seluruh saran, masukan dan kesempatan kepada tim jurnal. Semoga Jurnal Sinergy semakin maju hingga menjadi jurnal bereputasi. Demikianlah ucapan terimakasih ini penulis sampaikan dan lain waktu masih dapat bekerja sama lagi.

\section{DAFTAR PUSTAKA}

Darmanto., Sri Wardaya., Titik Dwiyani. (2015). Bauran orientasi strategi dan kinerja organisasi penerapan variable antesedan moderasi dan mediasi dalam penelitian ilmiah, Yoyakarta: CV. Budi Utama

Maroofi, F., Ardalan, A. G., \& Tabarzadi, J. (2017). The Effect Of Sales Strategies In The Financial Performance Of Insurance Companies. International Journal Of Asian Social Science, 11. 
Nasution, M. I., Prayogi, M. A., \& Nasution, S. M. A. (2107). Analisis Pengaruh Bauran Pemasaran Terhadap Volume Penjualan | Jurnal Riset Sains Manajemen. 1 (1).

Okura, M. (2007). Coopetitive Strategies of Japanese Insurance Firms A Game-Theory Approach. International Studies of Management \& Organization, 37(2), 53-69. https://doi.org/10.2753/IMO0020-8825370203.

Pamungkas*, S. B., Njatrijani, R., \& Saptono, H. (2017). Tanggung jawab perusahaan asuransi pt. Asuransi mitra maparya cabang semarang terhadap klaim kebakaran yang menimpa CV. Indoprinting semarang. Diponegoro law journal, 6(2), 1-13.

Pratama, A. A. (2017). Pengaruh Strategi Promosi Dan Kualitas Layanan Terhadap Peningkatan Penjualan Di Ovan Putri Bridal And Make Up Surabaya. 06, 6.

Rastuti, Tuti. 2016. Aspek Hukum perjanjian asuransi, Yogyakarta: Medpress Digital

Siregar, M. Y. (2017). Faktor-Faktor Yang Mempengaruhi Volume Penjualan Sparepart Pada PT. Calispo Multi Utama. 3(1), 16.

Sopiah dan Etta, Mamang, Sangadji. 2016. Salesmanship (kepenjualan), Jakarta: PT. Bumi Aksara 